\title{
A checklist of helminth fauna of weatherfish, Misgurnus fossilis (Pisces, Cobitidae): state of the art, species list and perspectives of further studies
}

\author{
M. POPIOŁEK ${ }^{*}$, J. KOTUSZ ${ }^{1}$
}

Department of Zoology and Ecology, Wrocław University of Environmental and Life Sciences, Kożuchowska 5b, 51631 Wrocław, Poland, E-mail: marcin.popiolek@up.wroc.pl; ${ }^{1}$ Museum of Natural History, Wrocław University, Sienkiewicza 21, 50-335 Wrocław, Poland, E-mail: kotusz@biol.uni.wroc.pl

\begin{abstract}
Summary
The helminth fauna of weatherfish (Misgurnus fossilis) in natural range is reviewed. Several helminth species reported in weatherfish are discussed with reference to host specificity and their geographical distribution. The current list of helminth parasites of the weatherfish includes 37 species. Most (15) are digenean trematodes, half of them being larval stages. Only one species of trematode - Allocreadium transversale is more specific parasite of weatherfish. Second largest group are Monogenea, with 10 species. Two of them (Gyrodactylus strelkovi and G. misgurni) are found only in the genus Misgurnus. Tapeworms (6 species) and Nematodes (6 species) are less numerous. No Acanthocephala, however, were ever found.
\end{abstract}

Key words: Misgurnus fossilis; helminth; parasites; geographical distribution

Information on parasites and parasitoses of fish species of no economic significance is still scanty, mainly due to their low abundance and difficulties in catching. Cobitids, including weatherfish, are among such fishes. The distribution of the weatherfish (Misgurnus fossilis) is limited to Europe except Great Britain, some Scandinavian countries, and the Pyrenean, Appeninic and Balkan Peninsulas. It is also absent from tributaries of rivers falling into the Mediterranean, Adriatic, Aegean and Arctic Seas (Kotusz, 2001). In many sites within its natural range it no longer exists. Industry and agriculture are regarded as the main reasons for its disappearance; they cause pollution and devastation of natural habitats (Kotusz, 2001). Diseases, including parasitoses, are also of great significance. However, the knowledge of weatherfish helminth fauna is still fragmentary; the latter pertains to both the species composition of parasites and to their geographical distribution. The parasites were rather unevenly studied and most data

\footnotetext{
${ }^{*}$ corresponding author
}

come from former USSR or Russia, Ukraine, Czech Republic, Slovakia and Poland, whereas the other parts of Europe (e.g. in Austria, Hungary) were only "insularly" and accidentally studied (Bychovskaja-Pavlovskaja, 1962; Grabda, 1971; Ergens et al., 1975; Kritscher, 1980, 1983, 1988; Prost, 1981; Kanev, 1984; Bauer, 1985, 1987; Movchan \& Smirnov, 1988; Moravec, 2001; Popiołek, 2002; Zhokhov, 2002; Popiołek et al., 2003).

The current list of helminth parasites of the weatherfish is quite long and includes 37 species (Table 1). Most (15) are digenean trematodes, half of them being larval stages. Among seven trematode species found in the weatherfish as adults, three represent the genus Sanguinicola (S. armata, $S$. inermis and S. intermedia). These parasites are located in the blood vessels which results in their high pathogenicity. According to Niewiadomska (2003) these trematodes are non-specific parasites of the weatherfish (they occur mainly in Tinca tinca, Cyprinus carpio and Carassius carassius), they have been recorded from this host, among others, from Poland, the Czech Republic, Slovakia and Ukraine (Movchan \& Smirnow, 1988; Moravec, 2001). Another two species of weatherfish parasites are members of the genus Sphaerostomum. Though Sph. bramae occurs mainly in the intestine of cyprinids, and in the weatherfish it has been noted accidentally and only in Russia and Ukraine, Sph. globiporum is included in the lists of weatherfish parasites and has been recorded from this host in Russia and Poland. According to Zhokhov (2002), for both these species the weatherfish is an atypical host. The only parasite specific for cobitids, including the weatherfish, is an intestinal species Allocreadium transversale. Because of the narrow host spectrum, the trematode has been recorded nearly everywhere where the weatherfish was dissected (see table). The presence of Asymphylodora macracetabulum on the list of weatherfish parasites published in the key of Bychovskaja-Pavlovskaja (1962) appears to be an error. The localities of the parasite men- 
Table 1. List of helminths species recorded from weatherfish, indicating parasite stage and geographic distributions with reference.

\begin{tabular}{|c|c|c|}
\hline Species of parasite & Stage & Distribution \\
\hline \multicolumn{3}{|l|}{ Monogenea } \\
\hline $\begin{array}{l}\text { Dactylogyrus extensus Mueller et Van Cleave, } \\
1932\end{array}$ & Adl & Czech Republic (1), Ukraine (2) \\
\hline D. vastator Nybelin, 1924 & Adl & Poland (3) \\
\hline Ancyrocephalus cruciatus (Wedl, 1857) & Adl & $\begin{array}{l}\text { Czech Republic (1), Slovakia (1), Ukraine }(2,16) \text {, Poland }(3,4) \text {, } \\
\text { Austria (5), former USSR (6) }\end{array}$ \\
\hline *Gyrodactylus cobitis Bychowsky, 1933 & Adl & Czech Republic (1), Slovakia (1), Ukraine (2), Poland (3) \\
\hline *G. elegans Nordmann, 1832 & Adl & Czech Republic (1), Slovakia (1), \\
\hline G. fossilis Lupu et Roman, 1956 & Adl & Czech Republic (1), Slovakia (1), former USSR (6) \\
\hline G. medius Kathariner, 1893 & Adl & Czech Republic (1) \\
\hline G. misgurni Ling, 1962 & Adl & $\begin{array}{l}\text { Czech Republic (1), Slovakia (1), Ukraine (16), Poland (3), } \\
\text { former USSR (6), Hungary (16) }\end{array}$ \\
\hline G. strelkovi Ergens et Danilov, 1983 & Adl & Former USSR (6) \\
\hline Diplozoon paradoxum Nordmann, 1832 & $\begin{array}{l}\text { Adl, } \\
\text { Larv }\end{array}$ & Ukraine (2), former USSR (7) \\
\hline \multicolumn{3}{|l|}{ Cestoda } \\
\hline${ }^{*}$ Paracaryophyllaeus gotoi (Motomura, 1927) & Adl & not specified or Russia (9) \\
\hline *Paraglaridacris limnodrili (Yamaguti, 1934) & Adl & not specified (9) \\
\hline Caryophyllaeidae gen. sp. & Adl & Slovakia (1) \\
\hline Proteocephalus sp. & Adl & Poland (8) \\
\hline $\begin{array}{l}\text { Neogryporhynchus cheilancristrotus (Wedl, } \\
1855)\end{array}$ & Larv & $\begin{array}{l}\text { Czech Republic (1), Slovakia }(1,16) \text {, Ukraine (2), Poland }(4,8) \text {, } \\
\text { Hungary (16) }\end{array}$ \\
\hline Valipora campylancristrota (Wedl, 1855) & Larv & Ukraine (2) \\
\hline \multicolumn{3}{|l|}{ Digenea } \\
\hline Sanguinicola armata Plehn, 1905 & Adl & Czech Republic (1), Ukraine (2), former USSR (6), Poland (10) \\
\hline S. inermis Plehn, 1905 & Adl & Czech Republic (1) \\
\hline S. intermedia Ejsmont, 1925 & Adl & Czech Republic (1), Slovakia (1), Ukraine (2) \\
\hline $\begin{array}{l}\text { *Asymphylodora macracetabulum Belouss, } \\
1953\end{array}$ & Adl & former USSR (7) \\
\hline Allocreadium transversale (Rudolphi, 1802) & Adl & $\begin{array}{l}\text { Czech Republic (1), Slovakia (1), Ukraine }(2,16) \text {, Poland }(8,11) \text {, } \\
\text { former USSR }(6,7) \text {, Austria (12), Hungary }(16)\end{array}$ \\
\hline Sphaerostomum bramae (Müller, 1776) & Adl & Ukraine (2), Poland (4), former USSR (7), Russia (13) \\
\hline Sph.. globiporum (Rudolphi, 1802) & Adl & Poland (4), former USSR (6,7), Russia (13) \\
\hline Echinostomatidae gen. sp. & Larv & Ukraine $(2,16)$, Hungary $(16)$ \\
\hline Diplostomum spathaceum (Rudolphi, 1819) & Larv & Czech Republic (1), Slovakia (1) \\
\hline Diplostomum sp. & Larv & Slovakia (1), Poland (8) \\
\hline Tylodelphys clavata (Nordmann, 1832) & Larv & Czech Republic (1), Slovakia $(1,16)$, Ukraine (16), Hungary (16) \\
\hline T. craniaria Diesing, 1858 & Larv & Poland (10) \\
\hline $\begin{array}{l}\text { Posthodiplostomum cuticola (Nordmann, } \\
\text { 1832) }\end{array}$ & Larv & $\begin{array}{l}\text { Czech Republic (1), Slovakia (1), Ukraine (2), Poland (8), } \\
\text { former USSR (6), Hungary (16) }\end{array}$ \\
\hline Clinostomum complanatum (Rudolphi, 1814) & Larv & Ukraine (2) \\
\hline Metagonimus yokogawai Katsurada, 1912 & Larv & Slovakia (1) \\
\hline \multicolumn{3}{|l|}{ Nematoda } \\
\hline $\begin{array}{l}\text { *Dichelyne (Cucullanellus) minutus (Rudolphi, } \\
\text { 1819) }\end{array}$ & Adl & Poland (14) \\
\hline Pseudocapillaria tomentosa (Dujardin, 1843) & Adl & Poland (8), not specified (15) \\
\hline Rhabdochona denudata (Dujardin, 1845) & Adl & Poland (8), Ukraine (16), Hungary (16) \\
\hline Raphidascaris acus (Bloch, 1779) & Larv & Slovakia (1), Ukraine (2), Poland (8) \\
\hline Spiroxys contortus (Rudolphi, 1819) & Larv & not specified (15) \\
\hline *Hysterothylacium aducnum (Rudolphi, 1802) & Larv & Ukraine (2) \\
\hline
\end{tabular}

* - Questionable host; Adl - adult stage; Larv - larval stage; (1) Moravec, 2001; (2) Movchan, \& Smirnov, 1988; (3) Prost, 1981; (4) Grabda, 1971; (5) Kritsher, 1988; (6) Bauer, 1985; (7) Bychovskaja-Pavlovskaja, 1962; (8) Popiołek, 2002; (9) Pojmańska, 1991; (10) Niewiadomska, 2003; (11) Popiołek et al., 2003; (12) Kritscher, 1983; (13) Zhokhov, 2002; (14) Grabda-Kazubska \& Okulewicz, 2005; (15) Moravec 1994, (16) Ergens et al., 1975.

tioned in this paper are incompatible with the weatherfish distribution range and have not been confirmed in a more recent publication by Bauer (1987). Besides, it is usually
Misgurnus anguillicaudatus that is mentioned as the host of A. macracetabulum, and attributing this role to M. fossilis is probably a mistake. The remaining trematodes re- 
corded from the weatherfish occur there only as larvae (metacercarie), and the fish is their intermediate host. Metacercarie found in the weatherfish represent four families: Diplostomidae, Clinostomidae Heterophyidae and Echinostomatidae. Among them Diplostomatidae are the most numerous; their larvae are usually located in the skin (e.g. Posthodiplostomum cuticola), eyes (Diplostomum spathaceum, Tylodelphys clavata), muscles, brain (T. craniaria) or the vertebral canal of the fish, while their adult forms occur in fish-eating birds or, less often, mammals. While three of the above-mentioned metacercariae are regarded as parasites of a rather wide host spectrum and recorded from most countries, T. cranicaria is a rare species, till now recorded only from lakes of northeast Poland and middle Odra River (Kozicka \& Niewiadomska, 1960; Dąbrowska, 1970). Representatives of the last two families are metacercarie characteristic of numerous percids and cyprinids. They are located on the skin, fins or in the muscles and body cavity. Metagonimus yokogawai has been recorded from the weatherfish in the Slovakia, and Clinostomum complanatum only in Ukraine. Members of the last group - Echinostomatidae have been identified only to the family level.

The next most numerous group includes 10 species of monogeneans, among them both specific parasites of the weatherfish and accidentally found species. The genus Gyrodactylus is the most numerously represented monogenean taxon in the weatherfish. Among its six species, four are more or less specific: G. misgurni and G. strelkovi occur only on the fins and gills of the M. fossilis and $M$. anguillicaudatus. G. fossilis is found also in Nemacheilus angorae and G. cobitis also in Cobitis taenia. The specificity of the remaining two species ( $G$. elegans and $G$. medius) is low, and their main hosts are numerous cyprinid species. Nevertheless, Harris et al. (2004) do not confirm occurrence of $G$. cobitis and $G$. elegans in weatherfish. The list of weatherfish parasites presented by Prost (1981) includes a sixth species, discovered in the weatherfish and specific to it - G. luckiensis. However, as a result of Ergens's (1986) revision the species turned out to be a synonym of G. misgurni and was consequently omitted from the present list. Another two monogeneans represent the genus Dactylogyrus. D. extensus has been repeatedly recorded from the weatherfish in the Czech Republic and Ukraina, but the single record of D. vastator from Poland (Prost, 1981) should be regarded as accidental, since the species occurs nearly exclusively in Carassius and farmed carp. The remaining monogeneans are: Ancyrocephalus cruciatus commonly found in the weatherfish, and Diplozoon paradoxum. The last species has been recorded from the weatherfish, both as adult stage and as larva (diporpa), till now only once, from Ukraine and former USSR.

Among the six tapeworms found in the weatherfish, two have been identified to the family level (Caryophyllaeidae gen. sp.) and genus level (Proteocephalus sp.). The only loaches-specific parasite, recorded from the weatherfish and spined loach (Cobitis taenia) is Paracaryophyllaeus gotoi, recorded from former USSR. Another two tape- worms: Paraglaridacris limnodrili and in particular, the larval stage of Neogryporhynchus cheilancristrotus are rather common parasites of cyprinids, but they have been recorded from the weatherfish on several occasions. The last tapeworm, the plerocercoid of Valiopora campylancristrota (under the name Ophiovalipora unilateralis), has been recorded from the weatherfish only by Movchan \& Smirnov (1988) in Ukraine. The record is, however, somewhat doubtful since it has never been confirmed. Also in the most recent paper by Scholz et al. (2004) on Cyclophyllidea neither the weatherfish nor any other cobitid are mentioned in the list of hosts of this tapeworm.

The group of six nematode species recorded from the weatherfish includes no host-specific parasites, and three of them occur only as larvae. Raphidascaris acus is most often found as an encysted third stage larva on the surface or inside the intestine, on internal organs, in the muscle or body cavity. This common nematode is a parasite of several dozen fishes of various families, and is also the most frequently recorded weatherfish nematode. Another parasite is the larval stage of Spiroxys contortus, which - like $R$. acus - is found as a cyst on the intestine wall or peritoneum of several cyprinids and predatory freshwater fishes. It has been recorded from the weatherfish in the catchment area of the Tisa River in Hungary (Moravec, 1994). The third species found in the weatherfish is the larva of Hysterothylacium aducnum, recorded only from Ukraine under the name Contracaecum aduncum. It appears that this record should be regarded as extremely accidental, since the role of main intermediate hosts for this nematode is attributed to marine fishes, and among its few freshwater hosts the weatherfish or other cobitids are not mentioned (Moravec, 1994). The remaining three nematode species recorded from the weatherfish as adult stages are located in the intestine. Pseudocapillaria tomentosa has a very wide range of hosts of various freshwater families, including Cobitidae. In the weatherfish it has been found only once, from Odra River basin in Poland (Popiołek, 2002). Information on finding Dichelyne (Cucullanellus) minutus at the weatherfish in Poland one laded from the monograph by Grabda-Kazubska \& Okulewicz (2005). However authors did not give any nearer data as well as the source publication. In consideration of that hosts of this parasite are exclusively sea- fish (mostly Pleuronectidae) the above ascertainment can be found not certain. Rhabdochona denudata is a common parasite of cyprinids, especially the genera Leuciscus and Rutilus. In his monograph, Moravec (1994) mentions also cobitids as potential hosts of this parasite, which confirms the record in the weatherfish from tributaries of middle Odra River in Poland and from Tisa River basin in Ukraine and Hungary (Ergens et al., 1975; Popiołek, 2002).

No Acanthocephala, however, were ever found.

Thirty-seven species of helminths hitherto recorded make the weatherfish the best studied species among all cobitids. However, the habitats occupied by the weatherfish, i.e. stagnant or slow-flowing and eutrophic water, characterised by rich and diversified invertebrate fauna, are very 
specific. As a result, such habitats create an optimal environment for life and development of almost all groups of parasites, which makes the fish particularly endangered by permanent ichtyoparasitoses.

Comparison of the helminth fauna of the weatherfish in different parts of its distribution range revealed differences between local host populations. At some localities, composition of parasite species is unique and dominated by allogenic species, for which weatherfish is only an intermediate host. Such a situation may result either from the natural conditions or from progressive anthropopressure. This suggests that continuation, and especially geographical extension, of the studies would increase the knowledge of weatherfish parasites and parasitoses, and contribute to more efficient protection of the species.

\section{Acknowledgements}

We are grateful to B. M. Pokryszko for revising English.

\section{References}

BAUER, O. N. (1985): Key to parasites of freshwater fishes of the fauna of the USSR. Part II. Nauka, Leningrad [In Russian]

BAUER O. N. (1987): Key to parasites of freshwater fishes of the fauna of the USSR. Part III. Nauka, Leningrad [In Russian]

Bychovskaja-Pavlovskaja, I. E., Gusev, A. V., Dubinina, M. V., IzJumowa, N. A., Smirnova, T. S., Sokolovskaja, I. L., Štein, G. A., Šulman, S. S., EPSTEIN, U. M. (1962): Key to parasites of freshwater fishes of the USSR. Publ. House of the USSR Acad. Sci. Moscow, Leningrad [In Russian]

DĄBROWSKA, Z. (1970): Fish parasites of the Vistula River near Warszawa. Acta Parasit. Pol., 17: 189 - 193

ERGENS, R. (1986): Notes on Gyrodactylus bychowskyi Sproston, 1946 sensu Lucky 1957 and G. luckiensis Prost, 1981 (Monogenea). Folia Parasitol., 33: 380

Ergens, R., Gussev, V. A., Izyumova, N. A., Molnar, K. (1975): Parasite fauna of the Tisa River basin. Rozpravy CASV, Academia, Praha

GrabDA, J. (1971): Catalogue of parasitic fauna of Poland. Parasites of Cyclostomates and Fishes. PWN, Warszawa, Wrocław [In Polish]

GrabDA-KaZUBSKA, B., OKUlewicz, A. (2005): Fish parasites of Poland (key to identification). Nematodes Nematoda. Polish Parasitological Society, Warszawa [In Polish]

Harris, P. D., Shinn, A. P., Cable, J., Bakke, T. A. (2004): Nominal species of the genus Gyrodactylus von Nordmann 1832 (Monogenea: Gyrodactylidae), with a list of principal host species. Syst. Parasitol., 59: $1-27$
KANEV, I. (1984): Occurrence of Cyathocotyle prussic Muhling, 1896 (Trematoda: Cyathocotylidae) in Bulgaria and some data on its biology. In VASILEV, I. (Ed.): Fauna, taxonomy end ecology of helminths of birds, Bulgaria, Bulgarian Academy of Sciencs, Sofia [In Bulgarian] Kotusz, J. (2001): Weatherfish, Misgurnus fossilis (L.). In GŁowAciŃski, Z. (Ed.): The Polish Red Data Book of Animals, PWRiL, Warszawa [In Polish]

Kozicka, J., NiewiadomskA, K. (1960): Studies on the biology and taxonomy of trematodes of the genus $T y$ lodelphys Diesing, 1850 (Diplostomatidae). Acta Parasit. Pol., 8: 379 - 401

KRITSCHER, E. (1980): Fishes of Neusiedlersee and their parasites. III. Acanthocephala. Ann. Nat. hist. Mus. Wien, B., 83: 641 - 650 [In German]

KRITSCHER, E. (1983): Fishes of the Neusiedlersee and their parasites. V. Trematoda: Digenea. Ann. Nat. hist. Mus. Wien, B., 85: 117 - 131 [In German]

KRITSCHER, E. (1988): Fish of the Neusiedlersee and their parasites. VII. Trematoda: Monogenea and summary of the series. Ann. Nat. hist. Mus. Wien, B., 90: 407 - 421 [In German]

MoraVeC, F. (1994): Parasitic nematodes of freshwater fishes of Europe. Academia, Praha

MORAVEC, F. (2001): Checklist of the metazoan parasites of fishes of the Czech Republic and the Slovak Republic (1873-2000). Academia, Praha

Movchan, Y. V., Smirnov, A. J. (1988): Fauna of Ukraine. VIII. Fishes. Naukova Dumka, Kiev [In Ukrainian]

NiEWIADOMSKA, K. (2003): Fish parasites of Poland (key to identification). Flatworms - Digenea. Polish Parasitological Society, Warszawa [In Polish]

PoJMAŃSKA, T. (1991): Fish parasites of Poland (key to identification). Tapeworms - Cestoda. Witlod Stefański Institute of Parasitology PAS, Warszawa [In Polish]

PopioŁeK, M. (2002): Helminth parasites of the weatherfish - Misgurnus fossilis (L.) (Cobitidae, Pisces) from tributaries of the middle Odra River basin (SW Poland). Helminthologia 39: 179

PopioŁeK, M., OKulewicz, J., Kotusz, J. (2003): The first record of Allocreadium transversale (Rudolphi, 1802) (Digenea, Allocreadiidae) from cobitid fishes of Poland. Helminthologia 40: 245 - 246

Prost, M. (1981): Fish Monogenea of Poland. VI. Parasites of Nemachilus barbatulus (L.) and Misgurnus fossilis (L.). Acta Parasit. Pol., 38: 1 - 10

Scholz, T., Bray, R. A., Kuchta, R., Repova, R. (2004): Larvae of gryporhynchid cestodes (Cyclophyllidea) from fish: a review. Folia Parasitol., 51: 131 - 152

ZHOKHOV, A. E. (2002): Host specificity of flukes of the genus Sphaerostomum (Trematoda: Opecoelidae) within their geographic ranges. Russ. J. Ecol., 33: 417 - 422 